\title{
MMF: Kodeks fiskalne transparentnosti
}

Izvršni odbor Međunarodnog monetarnog fonda usvojio je u kolovozu novi Kodeks fiskalne transparentnosti (The Fiscal Transparency Code) koji je tako postao standardom za sve članice MMF-a. Držeći fiskalnu transparentnost jednim od glavnih preduvjeta uspješnog upravljanja državnim financijama, MMF tim Kodeksom želi osigurati javnu dostupnost informacija i povećati odgovornost vlada prema tržištima, zakonodavnim tijelima i građanima. Institut za javne financije u cijelosti podržava sadržaj Kodeksa i njegovu primjenu u Hrvatskoj, te zato objavljuje ovaj prijevod, kao što je učinio is dvije ranije verzije 200I. i 20II. U nedavnom Aktualnom osvrtu Instituta, prokomentiran je jedan od značajnih noviteta Kodeksa - formalno uključivanje građana u odlučivanje o proračunu.

\section{A. NAČELA FISKALNE TRANSPARENTNOSTI}

\section{FiskaLnO IZVJEŠTAVANJE}

Fiskalna izvješća trebaju sadržavati sveobuhvatan, svrsishodan, pravovremen i pouzdan pregled fiskalnoga položaja i rada vlade.

I.I. Obuhvat: Fiskalna izvješća trebaju sadržavati sveobuhvatan pregled fiskalnih aktivnosti javnoga sektora i njegovih podsektora, prema međunarodnim standardima.

I.I.I. Obuhvat institucija: Fiskalna izvješća obuhvaćaju prema međunarodnim standardima sve subjekte uključene u javnu aktivnost.

I.I.2. Obuhvat stanja: Fiskalna izvješća uključuju bilancu stanja javne imovine, obveze i neto vrijednost. I.I.3. Obuhvat tokova: Fiskalna izvješća uključuju sve javne prihode, rashode i financiranje.

I.I.4. Obuhvat poreznih izdataka: Vlada redovito objavljuje i upravlja gubicima prihoda koji nastaju zbog poreznih izdataka.

1.2. Učestalost i pravovremenost: Fiskalna izvješća se moraju objavljivati često, redovito i pravovremeno.

I.2.I. Učestalost izvještavanja tijekom godine: Fiskalna izvješća tijekom godine objavljuju se često i redovito.

I.2.2. Pravovremenost godišnjih financijskih izvješća: Revidirana ili konačna godišnja financijska izvješća objavljuju se na vrijeme.

I.3. Kvaliteta: Informacije u fiskalnim izvješćima moraju biti svrsishodne, međunarodno usporedive te interno i povijesno konzistentne.

I.3.I. Klasifikacija: U fiskalnim izvješćima informacije se klasificiraju tako da pojašnjavaju upotrebu javnih resursa i olakšavaju međunarodne usporedbe. 
I.3.2. Unutarnja konzistentnost: Fiskalna izvješća interno su konzistentna i uključuju međusobno usklađene alternativne mjere zbirnih fiskalnih agregata.

I.3.3. Povijesne izmjene: Objavljuju se i objašnjavaju ključne izmjene povijesne fiskalne statistike.

I.4. Cjelovitost: Fiskalna statistika i financijska izvješća trebaju biti pouzdana, dostupna vanjskom nadzoru i moraju olakšavati utvrđivanje odgovornosti.

I.4.I. Statistička cjelovitost: Fiskalna se statistika prikuplja i objavljuje prema međunarodnim standardima.

I.4.2. Vanjska revizija: Visoka nezavisna revizijska institucija obavlja i objavljuje reviziju godišnjih financijskih izvješća i potvrđuje njihovu pouzdanost.

I.4.3. Usporedivost fiskalnih podataka: Fiskalna predviđanja, proračuni i fiskalna izvješća prikazuju se na usporedivoj osnovi, uz objašnjenja svih odstupanja.

\section{FISKALNA PREDVIĐANJA I PRORAČUNI}

Proračuni i fiskalna predviđanja na kojima se zasnivaju moraju sadržavati jasan stav o vladinim proračunskim ciljevima i poduzetim mjerama, uz sveobuhvatne, pravovremene i pouzdane projekcije razvoja javnih financija.

2.I. Sveobuhvatnost: Fiskalna predviđanja i proračuni moraju osigurati sveobuhvatan pregled budućih fiskalnih planova.

2.I.I. Jedinstvo proračuna: Prihodi, rashodi i financiranje svih subjekata središnje države u proračunskoj se dokumentaciji prikazuju na bruto osnovi te ih se odobrava u zakonodavnoj proceduri.

2.I.2. Makroekonomska predviđanja: Objavljuju se i objašnjavaju proračunske projekcije zasnovane na sveobuhvatnim makroekonomskim predviđanjima.

2.I.3. Srednjoročni proračunski okvir: Proračunska dokumentacija za srednjoročno razdoblje sadrži izvršenje i projekcije prihoda, rashoda i financiranja kao što je učinjeno i u godišnjem proračunu.

2.I.4. Investicijski projekti: Vlada redovito objavljuje svoje financijske obveze za višegodišnje investicijske projekte, a sve važne projekte podvrgava analizi koristi i troškova te otvorenom i konkurentnom tenderu (licitaciji).

2.2. Redovitost: Ovlasti i odgovornosti izvršne i zakonodavne vlasti u proračunskom procesu moraju biti zakonom definirani, a proračun treba biti predstavljen, raspravljan i usvojen na vrijeme.

2.2.I. Fiskalno zakonodavstvo: Zakonodavni okvir jasno definira vremenski raspored pripreme i usvajanja proračuna, ključnih sadržaja proračunske dokumentacije te ovlasti i odgovornosti izvršne i zakonodavne vlasti u proračunskom procesu.

2.2.2. Pravovremenost proračunskih dokumenata: Zakonodavnom tijelu i javnosti sustavno se pruža potrebno vrijeme za nadzor i odobrenje godišnjeg proračuna.

2.3. Usmjerenost politika: Fiskalna predviđanja i proračuni moraju biti predstavljeni tako da olakšavaju analizu mjera i utvrđivanje odgovornosti.

2.3.I. Ciljevi fiskalne politike: Vlada utvrđuje i obznanjuje jasne i mjerljive ciljeve javnih financija.

2.3.2. Informacije o izvršenju: Proračunska dokumentacija pruža informacije o ciljevima i rezultatima postignutim na svakom glavnom području vladinih mjera.

2.3.3. Sudjelovanje javnosti: Vlada građanima pruža razumljiv sažetak implikacija proračunskih mjera, uz njihovo sudjelovanje u odlučivanju o proračunu. 
2.4. Pouzdanost: Ekonomska i fiskalna predviđanja i proračuni moraju biti pouzdani.

2.4.I. Nezavisna evaluacija: Vladina ekonomska i fiskalna predviđanja i njihovo izvršenje predmet su nezavisne evaluacije.

2.4.2. Dopunski proračun: Svaka materijalna promjena odobrenog proračuna usvaja se u zakonodavnoj proceduri.

2.4.3. Usklađenost predviđanja: U proračunskoj dokumentaciji i svakom njenom sljedećem ažuriranju objašnjene su sve materijalne promjene vladinih prethodnih fiskalnih predviđanja, razlikujući fiskalni učinak novih mjera od onih prvotnih.

\section{ANALIZA I UPRAVLJANJE FISKALNIM RIZICIMA}

\section{Vlade trebaju objavljivati, analizirati i upravljati rizicima javnih financija i osigurati efikasnu koordinaciju fiskalnog odlučivanja u okviru cijelog javnog sektora.}

3.I. Objava rizika i analize: Vlade trebaju redovito objavljivati sažeta izvješća o rizicima fiskalnih predviđanja.

3.I.I. Makroekonomski rizici: Vlada izvještava o mogućim odstupanjima fiskalnih rezultata u odnosu na osnovna predviđanja, kao rezultat različitih makroekonomskih pretpostavki.

3.I.2. Posebni fiskalni rizici: Vlada pruža redovito sažeto izvješće o glavnim posebnim rizicima u fiskalnim predviđanjima.

3.I.3. Analize dugoročne fiskalne održivosti: Vlada redovito objavljuje dugoročne projekcije razvoja javnih financija.

3.2. Upravljanje rizicima: Posebne rizike u javnim financijama treba redovito nadzirati, objavljivati te s njima upravljati.

3.2.I. Nepredviđene okolnosti vezane uz proračun: U proračunu su transparentno alocirana dovoljna sredstva za nepredviđene okolnosti koje se javljaju tijekom izvršenja proračuna.

3.2.2. Upravljanje imovinom i obvezama: Upravlja se rizicima vezanim uz glavne oblike imovine i obveza te ih se objavljuje.

3.2.3. Jamstva: Izloženost vlade jamstvima redovito se objavljuje i zakonski odobrava.

3.2.4. Javno privatno-partnerstvo: Obveze u javno-privatnom partnerstvu redovito se objavljuju te se njima aktivno upravlja.

3.2.5. Izloženost financijskom sektoru: Vladina potencijalna fiskalna izloženost financijskom sektoru se analizira, objavljuje te se njome upravlja.

3.2.6. Prirodni resursi: Vladin udio u neobnovljivim prirodnim resursima i njihovo iskorištavanje se vrednuje, objavljuje i njima se upravlja.

3.2.7. Rizici po okoliš: Potencijalna fiskalna izloženost prirodnim nepogodama i drugim većim rizicima po okoliš se analizira, objavljuje i njome se upravlja.

3.3. Fiskalna koordinacija: Fiskalni odnosi i rezultati u cijelom javnom sektoru trebaju se analizirati, objavljivati i koordinirati.

3.3.I. Lokalne jedinice: Prikupljaju se i objavljuju sveobuhvatne informacije o financijskom stanju i rezultatima lokalnih jedinica - zasebno i konsolidirano za sve lokalne jedinice.

3.3.2. Javna poduzeća: Vlada redovito objavljuje sveobuhvatne informacije o financijskim rezultatima javnih poduzeća, uključujući sve njihove kvazi-fiskalne aktivnosti. 


\section{B. OPIS TEMELJNIH, DOBRIH I NAPREDNIH PRAKSI PREMA NAČELIMA}

\begin{tabular}{|c|c|c|c|c|c|}
\hline \multirow{2}{*}{ BR. } & \multirow{2}{*}{ MJERA } & \multirow{2}{*}{ NAČELO } & \multicolumn{3}{|c|}{ PRAKSA } \\
\hline & & & TEMELJNA & DOBRA & NAPREDNA \\
\hline I. & $\begin{array}{l}\text { Fiskalno } \\
\text { izvještavanje }\end{array}$ & \multicolumn{4}{|c|}{$\begin{array}{l}\text { Fiskalna izvješća trebaju sadržavati sveobuhvatan, svrsishodan, pravovremen i pouzdan } \\
\text { pregled fiskalnoga položaja i rada vlade. }\end{array}$} \\
\hline I.I. & Obuhvat & \multicolumn{4}{|c|}{$\begin{array}{l}\text { Fiskalna izvješća trebaju sadržavati sveobuhvatan pregled fiskalnih aktivnosti javnoga sektora } \\
\text { i njegovih podsektora, prema međunarodnim standardima. }\end{array}$} \\
\hline I.I.I. & $\begin{array}{l}\text { Obuhvat } \\
\text { institucija }\end{array}$ & $\begin{array}{l}\text { Fiskalna izvješća } \\
\text { obuhvaćaju prema } \\
\text { međunarodnim } \\
\text { standardima sve } \\
\text { subjekte uključene } \\
\text { u javnu aktivnost. }\end{array}$ & $\begin{array}{l}\text { U fiskalnim izvješćima } \\
\text { konsolidiraju se prema } \\
\text { međunarodnim } \\
\text { standardima svi } \\
\text { subjekti središnje } \\
\text { države. }\end{array}$ & $\begin{array}{l}\text { U fiskalnim izvješćima } \\
\text { konsolidiraju se svi } \\
\text { subjekti opće države, } \\
\text { a o svakom se } \\
\text { podsektoru izvještava } \\
\text { prema međunarodnim } \\
\text { standardima. }\end{array}$ & $\begin{array}{l}\text { U fiskalnim izvješćima } \\
\text { konsolidiraju se svi } \\
\text { subjekti javnog sektora, } \\
\text { a o svakom se } \\
\text { podsektoru izvještava } \\
\text { prema međunarodnim } \\
\text { standardima. }\end{array}$ \\
\hline I.I.2. & Obuhvat stanja & $\begin{array}{l}\text { Fiskalna izvješća } \\
\text { uključuju bilancu } \\
\text { stanja javne } \\
\text { imovine, obveze } \\
\text { i neto vrijednost. }\end{array}$ & $\begin{array}{l}\text { Fiskalna izvješća } \\
\text { uključuju gotovinu } \\
\text { i depozite i cijeli dug. }\end{array}$ & $\begin{array}{l}\text { Fiskalna izvješća } \\
\text { uključuju svu } \\
\text { financijsku imovinu } \\
\text { i obveze. }\end{array}$ & $\begin{array}{l}\text { Fiskalna izvješća } \\
\text { uključuju svu } \\
\text { financijskui } \\
\text { nefinancijsku imovinu, } \\
\text { obveze i neto } \\
\text { vrijednost. }\end{array}$ \\
\hline I.I.3. & Obuhvat tokova & $\begin{array}{l}\text { Fiskalna izvješća } \\
\text { uključuju sve javne } \\
\text { prihode, rashode } \\
\text { i financiranje. }\end{array}$ & $\begin{array}{l}\text { Fiskalna izvješća } \\
\text { uključuju gotovinske } \\
\text { prihode, rashode } \\
\text { i financiranje. }\end{array}$ & $\begin{array}{l}\text { Fiskalna izvješća } \\
\text { uključuju gotovinske } \\
\text { tokove, obračunske } \\
\text { prihode, rashode } \\
\text { i financiranje. }\end{array}$ & $\begin{array}{l}\text { Fiskalna izvješća } \\
\text { uključuju gotovinske } \\
\text { tokove, obračunske } \\
\text { prihode, rashode } \\
\text { financiranje i ostale } \\
\text { ekonomske tokove. }\end{array}$ \\
\hline I.I.4. & $\begin{array}{l}\text { Obuhvat poreznih } \\
\text { izdataka }\end{array}$ & $\begin{array}{l}\text { Vlada redovito } \\
\text { objavljuje i upravlja } \\
\text { gubicima prihoda } \\
\text { koji nastaju zbog } \\
\text { poreznih izdataka. }\end{array}$ & $\begin{array}{l}\text { Procijenjeni gubitak } \\
\text { prihoda od poreznih } \\
\text { izdataka objavljuje se } \\
\text { barem jednom } \\
\text { godišnje. }\end{array}$ & $\begin{array}{l}\text { Gubitak prihoda od } \\
\text { poreznih izdataka } \\
\text { procjenjuje se po } \\
\text { sektorima ili } \\
\text { područjima politike } \\
\text { i objavljuje se barem } \\
\text { jednom godišnje. }\end{array}$ & $\begin{array}{l}\text { Gubitak prihoda od } \\
\text { poreznih izdataka } \\
\text { procjenjuje se po } \\
\text { sektorima ili } \\
\text { područjima politike } \\
\text { i objavljuje se barem } \\
\text { jednom godišnje. } \\
\text { Kontroliraju se } \\
\text { proračunski ciljevi } \\
\text { i veličine poreznih } \\
\text { izdataka. }\end{array}$ \\
\hline
\end{tabular}

\begin{tabular}{|c|c|c|c|c|c|}
\hline I.2. & $\begin{array}{l}\text { Učestalost i } \\
\text { pravovremenost }\end{array}$ & \multicolumn{4}{|c|}{ Fiskalna izvješća se moraju objavljivati često, redovito i pravovremeno. } \\
\hline I.2.I. & $\begin{array}{l}\text { Učestalost } \\
\text { izvještavanja } \\
\text { tijekom godine }\end{array}$ & $\begin{array}{l}\text { Fiskalna izvješća } \\
\text { tijekom godine } \\
\text { objavljuju se često } \\
\text { i redovito. }\end{array}$ & $\begin{array}{l}\text { Fiskalna izvješća } \\
\text { tijekom godine } \\
\text { objavljuju se kvartalno, } \\
\text { tijekom kvartala. }\end{array}$ & $\begin{array}{l}\text { Fiskalna izvješća } \\
\text { tijekom godine } \\
\text { objavljuju se kvartalno, } \\
\text { tijekom mjeseca. }\end{array}$ & $\begin{array}{l}\text { Fiskalna izvješća } \\
\text { tijekom godine } \\
\text { objavljuju se mjesečno, } \\
\text { tijekom mjeseca. }\end{array}$ \\
\hline I.2.2. & $\begin{array}{l}\text { Pravovremenost } \\
\text { godišnjih } \\
\text { financijskih } \\
\text { izvješća }\end{array}$ & $\begin{array}{l}\text { Revidirana ili } \\
\text { konačna godišnja } \\
\text { financijska izvješća } \\
\text { objavljuju se na } \\
\text { vrijeme. }\end{array}$ & $\begin{array}{l}\text { Revidirana i konačna } \\
\text { godišnja financijska } \\
\text { izvješća objavljuju se } \\
\text { unutar I2 mjeseci do } \\
\text { kraja financijske } \\
\text { godine. }\end{array}$ & $\begin{array}{l}\text { Revidirana i konačna } \\
\text { godišnja financijska } \\
\text { izvješća objavljuju se } \\
\text { unutar } 9 \text { mjeseci do } \\
\text { kraja financijske } \\
\text { godine. }\end{array}$ & $\begin{array}{l}\text { Revidirana i konačna } \\
\text { godišnja financijska } \\
\text { izvješća objavljuju se } \\
\text { unutar } 6 \text { mjeseci do } \\
\text { kraja financijske } \\
\text { godine. }\end{array}$ \\
\hline I.3. & Kvaliteta & \multicolumn{4}{|c|}{$\begin{array}{l}\text { Informacije u fiskalnim izvješćima moraju biti svrsishodne, međunarodno usporedive te interno } \\
\text { i povijesno konzistentne. }\end{array}$} \\
\hline I.3.I. & Klasifikacija & $\begin{array}{l}\text { U fiskalnim } \\
\text { izvješćima } \\
\text { informacije se } \\
\text { klasificiraju tako } \\
\text { da pojašnjavaju } \\
\text { upotrebu javnih } \\
\text { resursa i olakšavaju } \\
\text { međunarodne } \\
\text { usporedbe. }\end{array}$ & $\begin{array}{l}\text { Fiskalna izvješća, gdje } \\
\text { je moguće, uključuju } \\
\text { organizacijskui } \\
\text { ekonomsku } \\
\text { klasifikaciju prema } \\
\text { međunarodnim } \\
\text { standardima. }\end{array}$ & $\begin{array}{l}\text { Fiskalna izvješća, gdje } \\
\text { je moguće, uključuju } \\
\text { organizacijsku, } \\
\text { ekonomskui } \\
\text { funkcijsku klasifikaciju } \\
\text { prema međunarodnim } \\
\text { standardima. }\end{array}$ & $\begin{array}{l}\text { Fiskalna izvješća, gdje } \\
\text { je moguće, uključuju } \\
\text { organizacijsku, } \\
\text { ekonomsku, funkcijsku } \\
\text { i programsku } \\
\text { klasifikaciju prema } \\
\text { međunarodnim } \\
\text { standardima. }\end{array}$ \\
\hline
\end{tabular}




\begin{tabular}{|c|c|c|}
\hline BR. & MJERA & NAČELO \\
\hline I.3.2. & $\begin{array}{l}\text { Unutarnja } \\
\text { konzistentnost }\end{array}$ & $\begin{array}{l}\text { Fiskalna izvješća } \\
\text { interno su } \\
\text { konzistentna } \\
\text { i uključuju } \\
\text { međusobno } \\
\text { usklađene } \\
\text { alternativne mjere } \\
\text { zbirnih fiskalnih } \\
\text { agregata. }\end{array}$ \\
\hline
\end{tabular}

$\begin{array}{ll}\text { I.3.3. } \quad \text { Povijesne izmjene } & \begin{array}{l}\text { Objavljuju se } \\ \text { i objašnjavaju } \\ \text { ključne izmjene } \\ \text { povijesne fiskalne } \\ \text { statistike. }\end{array}\end{array}$

\begin{tabular}{|c|c|c|}
\hline \multicolumn{3}{|c|}{ PRAKSA } \\
\hline TEmeljna & DOBRA & NAPREDNA \\
\hline $\begin{array}{l}\text { Fiskalna izvješća } \\
\text { uključuju barem jednu } \\
\text { od sljedećih } \\
\text { usklađenosti: I.) fiskalni } \\
\text { saldo i financiranje; } 2 \text {.) } \\
\text { izdani dug i njegove } \\
\text { vjerovnike, ili 3.) } \\
\text { financiranje i } \\
\text { promjenu stanja duga. }\end{array}$ & $\begin{array}{l}\text { Fiskalna izvješća } \\
\text { uključuju barem dvije } \\
\text { od sljedećih } \\
\text { usklađenosti: r.) } \\
\text { fiskalni saldo i } \\
\text { financiranje; 2.) izdani } \\
\text { dug i njegove } \\
\text { vjerovnike, ili 3.) } \\
\text { financiranje i } \\
\text { promjenu stanja duga. }\end{array}$ & $\begin{array}{l}\text { Fiskalna izvješća } \\
\text { uključuju sve tri } \\
\text { usklađenosti: I.) } \\
\text { fiskalni saldo i } \\
\text { financiranje; 2.) izdani } \\
\text { dug i njegove } \\
\text { vjerovnike, i 3.) } \\
\text { financiranje i } \\
\text { promjenu stanja duga. }\end{array}$ \\
\hline $\begin{array}{l}\text { Izvještava se o ključnim } \\
\text { izmjenama povijesne } \\
\text { fiskalne statistike. }\end{array}$ & $\begin{array}{l}\text { Izvještava se o } \\
\text { ključnim izmjenama } \\
\text { povijesne fiskalne } \\
\text { statistike uz } \\
\text { objašnjenja svake } \\
\text { glavne izmjene. }\end{array}$ & $\begin{array}{l}\text { Izvještava se o ključnim } \\
\text { izmjenama povijesne } \\
\text { fiskalne statistike uz } \\
\text { objašnjenja svake } \\
\text { glavne izmjene i uz } \\
\text { veznu tablicu između } \\
\text { starih i novih } \\
\text { vremenskih serija. }\end{array}$ \\
\hline
\end{tabular}

\begin{tabular}{|c|c|c|c|c|c|}
\hline I.4. & Gjelovitost & \multicolumn{4}{|c|}{$\begin{array}{l}\text { Fiskalna statistika i financijska izvješća trebaju biti pouzdana, dostupna vanjskom nadzoru } \\
\text { i moraju olakšavati utvrđivanje odgovornosti. }\end{array}$} \\
\hline I.4.I. & $\begin{array}{l}\text { Statistička } \\
\text { cjelovitost }\end{array}$ & $\begin{array}{l}\text { Fiskalna se statistika } \\
\text { prikuplja i objavljuje } \\
\text { prema } \\
\text { međunarodnim } \\
\text { standardima. }\end{array}$ & $\begin{array}{l}\text { Fiskalna se statistika } \\
\text { objavljuje prema } \\
\text { međunarodnim } \\
\text { standardima. }\end{array}$ & $\begin{array}{l}\text { Fiskalnu statistiku } \\
\text { prikuplja posebna } \\
\text { vladina agencija i } \\
\text { objavljuje prema } \\
\text { međunarodnim } \\
\text { standardima. }\end{array}$ & $\begin{array}{l}\text { Fiskalnu statistiku } \\
\text { prikuplja profesionalno } \\
\text { nezavisno tijelo i } \\
\text { objavljuje prema } \\
\text { međunarodnim } \\
\text { standardima. }\end{array}$ \\
\hline I.4.2. & Vanjska revizija & $\begin{array}{l}\text { Visoka nezavisna } \\
\text { revizijska institucija } \\
\text { obavlja } \\
\text { i objavljuje reviziju } \\
\text { godišnjih } \\
\text { financijskih izvješća } \\
\text { i potvrđuje njihovu } \\
\text { pouzdanost. }\end{array}$ & $\begin{array}{l}\text { Visoka nezavisna } \\
\text { revizijska institucija } \\
\text { objavljuje revizijsko } \\
\text { izvješće o pouzdanosti } \\
\text { godišnjih vladinih } \\
\text { financijskih izvješća. }\end{array}$ & $\begin{array}{l}\text { Visoka nezavisna } \\
\text { revizijska institucija } \\
\text { objavljuje, bez } \\
\text { ograničenja ili } \\
\text { suprotnih revizijskih } \\
\text { mišljenja, revizorsko } \\
\text { izvješce u kojem } \\
\text { ocjenjuje sadrže li } \\
\text { godišnja vladina } \\
\text { financijska izvješća } \\
\text { istinit i jasan pregled } \\
\text { njezine financijske } \\
\text { pozicije. }\end{array}$ & $\begin{array}{l}\text { Visoka nezavisna } \\
\text { revizijska institucija } \\
\text { objavljuje, u skladu } \\
\text { s međunarodnim } \\
\text { standardima, revizijsko } \\
\text { izvješće s ocjenom } \\
\text { predstavljaju li godišnja } \\
\text { vladina financijska } \\
\text { izvješća istinit i jasan } \\
\text { pogled njezine } \\
\text { financijske pozicije bez } \\
\text { većih ograničenja. }\end{array}$ \\
\hline I.4.3. & $\begin{array}{l}\text { Usporedivost } \\
\text { fiskalnih podataka }\end{array}$ & $\begin{array}{l}\text { Fiskalna } \\
\text { predviđanja, } \\
\text { proračuni i fiskalna } \\
\text { izvješća prikazuju se } \\
\text { na usporedivoj } \\
\text { osnovi, uz } \\
\text { objašnjenja svih } \\
\text { odstupanja. }\end{array}$ & $\begin{array}{l}\text { Barem jedno fiskalno } \\
\text { izvješce je napravljeno } \\
\text { na istoj osnovi kao } \\
\text { fiskalna } \\
\text { predviđanja/proračun. }\end{array}$ & $\begin{array}{l}\text { Fiskalna } \\
\text { predviđanja/proračun } \\
\text { i izvršenje su } \\
\text { usporedivi, te je } \\
\text { izvršenje u skladu s } \\
\text { fiskalnom statistikom } \\
\text { ili konačnim } \\
\text { obračunima. }\end{array}$ & $\begin{array}{l}\text { Fiskalna } \\
\text { predviđanja/proračun } \\
\text { i izvršenje su } \\
\text { usporedivi, te je } \\
\text { izvršenje u skladu s } \\
\text { fiskalnom statistikom i } \\
\text { konačnim obračunima. }\end{array}$ \\
\hline 2. & $\begin{array}{l}\text { Fiskalna } \\
\text { predviđanja } \\
\text { i proračuni }\end{array}$ & \multicolumn{4}{|c|}{$\begin{array}{l}\text { Proračuni i fiskalna predviđanja na kojima se zasnivaju moraju sadržavati jasan stav } \\
\text { o vladinim proračunskim ciljevima i poduzetim mjerama, uz sveobuhvatne, pravovremene } \\
\text { i pouzdane projekcije razvoja javnih financija. }\end{array}$} \\
\hline 2.I. & Sveobuhvatnost & \multicolumn{4}{|c|}{$\begin{array}{l}\text { Fiskalna predviđanja i proračuni moraju osigurati sveobuhvatan pregled budućih fiskalnih } \\
\text { planova. }\end{array}$} \\
\hline 2.I.I. & $\begin{array}{l}\text { Jedinstvo } \\
\text { proračuna }\end{array}$ & $\begin{array}{l}\text { Prihodi, rashodi i } \\
\text { financiranje svih } \\
\text { subjekata središnje } \\
\text { države u } \\
\text { proračunskoj se } \\
\text { dokumentaciji } \\
\text { prikazuju na bruto } \\
\text { osnovi te ih se } \\
\text { odobrava u } \\
\text { zakonodavnoj } \\
\text { proceduri. }\end{array}$ & $\begin{array}{l}\text { Proračunska } \\
\text { dokumentacija } \\
\text { uključuje sve bruto } \\
\text { domaće porezne } \\
\text { prihode, rashode } \\
\text { i financiranje } \\
\text { ministarstava i agencija } \\
\text { središnje države. }\end{array}$ & $\begin{array}{l}\text { Proračunska } \\
\text { dokumentacija } \\
\text { uključuje sve bruto } \\
\text { domaće porezne i } \\
\text { neporezne prihode, } \\
\text { rashode i financiranje } \\
\text { ministarstava, agencija } \\
\text { i izvanproračunskih } \\
\text { fondova središnje } \\
\text { države. }\end{array}$ & $\begin{array}{l}\text { Proračunska } \\
\text { dokumentacija } \\
\text { uključuje sve bruto } \\
\text { domaće i inozemne } \\
\text { prihode, rashode i } \\
\text { financiranje } \\
\text { ministarstava, agencija } \\
\text { i izvanproračunskih } \\
\text { fondova i fondova } \\
\text { socijalne sigurnosti } \\
\text { središnje države. }\end{array}$ \\
\hline
\end{tabular}




\begin{tabular}{|c|c|c|c|c|c|}
\hline \multirow{2}{*}{ BR. } & \multirow{2}{*}{ MJERA } & \multirow{2}{*}{ NAČELO } & \multicolumn{3}{|c|}{ Praksa } \\
\hline & & & TEMELJNA & DOBRA & NAPREDNA \\
\hline 2.I.2. & $\begin{array}{l}\text { Makroekonomska } \\
\text { predviđanja }\end{array}$ & $\begin{array}{l}\text { Objavljuju se } \\
\text { i objašnjavaju } \\
\text { proračunske } \\
\text { projekcije } \\
\text { zasnovane na } \\
\text { sveobuhvatnim } \\
\text { makroekonomskim } \\
\text { predviđanjima. }\end{array}$ & $\begin{array}{l}\text { Proračunska } \\
\text { dokumentacija } \\
\text { uključuje predviđanja } \\
\text { ključnih } \\
\text { makroekonomskih } \\
\text { varijabli. }\end{array}$ & $\begin{array}{l}\text { Proračunska } \\
\text { dokumentacija } \\
\text { uključuje predviđanja } \\
\text { ključnih } \\
\text { makroekonomskih } \\
\text { varijabli i pretpostavke } \\
\text { na kojim se temelje. }\end{array}$ & $\begin{array}{l}\text { Proračunska } \\
\text { dokumentacija } \\
\text { uključuje predviđanja } \\
\text { i objašnjenja ključnih } \\
\text { makroekonomskih } \\
\text { varijabli i njihovih } \\
\text { komponenti, kao i } \\
\text { pretpostavke na kojima } \\
\text { se temelje. }\end{array}$ \\
\hline 2.I.3. & $\begin{array}{l}\text { Srednjoročni } \\
\text { proračunski okvir }\end{array}$ & $\begin{array}{l}\text { Proračunska } \\
\text { dokumentacija za } \\
\text { srednjoročno } \\
\text { razdoblje sadrži } \\
\text { izvršenje i } \\
\text { projekcije prihoda, } \\
\text { rashoda i } \\
\text { financiranja kao } \\
\text { što je učinjeno } \\
\text { i u godišnjem } \\
\text { proračunu. }\end{array}$ & $\begin{array}{l}\text { Proračunska } \\
\text { dokumentacija sadrži } \\
\text { izvršenje za dvije } \\
\text { prethode godine } \\
\text { i srednjoročne } \\
\text { projekcije ukupnih } \\
\text { prihoda, rashoda i } \\
\text { financiranja. }\end{array}$ & $\begin{array}{l}\text { Proračunska } \\
\text { dokumentacija sadrži } \\
\text { izvršenje za dvije } \\
\text { prethode godine } \\
\text { i srednjoročne } \\
\text { projekcije prihoda, } \\
\text { rashoda i financiranja } \\
\text { po ekonomskim } \\
\text { kategorijama. }\end{array}$ & $\begin{array}{l}\text { Proračunska } \\
\text { dokumentacija sadrži } \\
\text { izvršenje za dvije } \\
\text { prethode godine } \\
\text { i srednjoročne } \\
\text { projekcije prihoda, } \\
\text { rashoda i financiranja } \\
\text { po ekonomskim } \\
\text { kategorijama i po } \\
\text { programima. }\end{array}$ \\
\hline 2.I.4. & $\begin{array}{l}\text { Investicijski } \\
\text { projekti }\end{array}$ & $\begin{array}{l}\text { Vlada redovito } \\
\text { objavljuje svoje } \\
\text { financijske obveze } \\
\text { za višegodišnje } \\
\text { investicijske } \\
\text { projekte, a sve važne } \\
\text { projekte podvrgava } \\
\text { analizi koristi } \\
\text { i troškova } \\
\text { te otvorenom } \\
\text { i konkurentnom } \\
\text { tenderu (licitaciji). }\end{array}$ & $\begin{array}{l}\text { Primjenjuje se jedno } \\
\text { od sljedećeg: I.) vlada } \\
\text { redovito objavljuje } \\
\text { vrijednost svih svojih } \\
\text { obveza u okviru } \\
\text { višegodišnjih } \\
\text { investicijskih } \\
\text { projekata; 2.) prije } \\
\text { odobravanja, sve glavne } \\
\text { projekte podvrgava } \\
\text { analizi troškova } \\
\text { i koristi, } \\
\text { te ju objavljuje; ili 3.) } \\
\text { zahtijeva da se svi } \\
\text { glavni projekti } \\
\text { ugovaraju temeljem } \\
\text { konkurentnog tendera. }\end{array}$ & $\begin{array}{l}\text { Primjenjuje se dvoje } \\
\text { od sljedećeg: I.) vlada } \\
\text { redovito objavljuje } \\
\text { vrijednost svih svojih } \\
\text { obveza u okviru } \\
\text { višegodišnjih } \\
\text { investicijskih } \\
\text { projekata; 2.) prije } \\
\text { odobravanja, sve } \\
\text { glavne projekte } \\
\text { podvrgava analizi } \\
\text { troškova i koristi, } \\
\text { te ju objavljuje; ili } 3 .) \\
\text { zahtijeva da se svi } \\
\text { glavni projekti } \\
\text { ugovaraju temeljem } \\
\text { konkurentnog } \\
\text { tendera. }\end{array}$ & $\begin{array}{l}\text { Primjenjuje se sve } \\
\text { sljedeće: I.) vlada } \\
\text { redovito objavljuje } \\
\text { vrijednost svih svojih } \\
\text { obveza u okviru } \\
\text { višegodišnjih } \\
\text { investicijskih } \\
\text { projekata; 2.) prije } \\
\text { odobravanja, sve glavne } \\
\text { projekte podvrgava } \\
\text { analizi troškova i } \\
\text { koristi, te ju objavljuje; } \\
\text { i 3.) zahtijeva da se svi } \\
\text { glavni projekti } \\
\text { ugovaraju temeljem } \\
\text { konkurentnog tendera. }\end{array}$ \\
\hline 2.2. & Redovitost & $\begin{array}{l}\text { Ovlasti i odgovor } \\
\text { zakonom definirar }\end{array}$ & $\begin{array}{l}\text { izvršne i zakonod } \\
\text { roračun treba biti p }\end{array}$ & $\begin{array}{l}\text { vlasti u proračun } \\
\text { tavljen, raspravljan }\end{array}$ & $\begin{array}{l}\text { procesu moraju biti } \\
\text { jen na vrijeme. }\end{array}$ \\
\hline 2.2.I. & $\begin{array}{l}\text { Fiskalno } \\
\text { zakonodavstvo }\end{array}$ & $\begin{array}{l}\text { Zakonodavni okvir } \\
\text { jasno definira } \\
\text { vremenski } \\
\text { raspored pripreme } \\
\text { i usvajanja } \\
\text { proračuna, ključnih } \\
\text { sadržaja } \\
\text { proračunske } \\
\text { dokumentacije } \\
\text { te ovlasti i } \\
\text { odgovornosti } \\
\text { izvršne i } \\
\text { zakonodavne vlasti } \\
\text { u proračunskom } \\
\text { procesu. }\end{array}$ & $\begin{array}{l}\text { Zakonodavni okvir } \\
\text { jasno definira jedno od } \\
\text { sljedećeg: r.) } \\
\text { vremenski raspored } \\
\text { pripreme i usvajanja } \\
\text { proračuna; 2.) ključni } \\
\text { sadržaj prijedloga } \\
\text { proračuna izvršne } \\
\text { vlasti; ili 3.) zakonsko } \\
\text { pravo da se izmijeni } \\
\text { prijedlog proračuna } \\
\text { izvršne vlasti. }\end{array}$ & $\begin{array}{l}\text { Zakonodavni okvir } \\
\text { jasno definira dvoje } \\
\text { od sljedećeg: I.) } \\
\text { vremenski raspored } \\
\text { pripreme i usvajanja } \\
\text { proračuna; } 2 .) \text { ključni } \\
\text { sadržaj prijedloga } \\
\text { proračuna izvršne } \\
\text { vlasti; ili 3.) zakonsko } \\
\text { pravo da se izmijeni } \\
\text { prijedlog proračuna } \\
\text { izvršne vlasti. }\end{array}$ & $\begin{array}{l}\text { Zakonodavni okvir } \\
\text { jasno definira sve } \\
\text { navedeno: I.) } \\
\text { vremenski raspored } \\
\text { pripreme i usvajanja } \\
\text { proračuna; } 2 .) \text { ključni } \\
\text { sadržaj prijedloga } \\
\text { proračuna izvršne } \\
\text { vlasti; i 3.) zakonsko } \\
\text { pravo da se izmijeni } \\
\text { prijedlog proračuna } \\
\text { izvršne vlasti. }\end{array}$ \\
\hline 2.2.2. & $\begin{array}{l}\text { Pravovremenost } \\
\text { proračunskih } \\
\text { dokumenata }\end{array}$ & $\begin{array}{l}\text { Zakonodavnom } \\
\text { tijelu i javnosti } \\
\text { sustavno se pruža } \\
\text { potrebno vrijeme za } \\
\text { nadzor i odobrenje } \\
\text { godišnjeg } \\
\text { proračuna. }\end{array}$ & $\begin{array}{l}\text { Proračun se dostavlja } \\
\text { zakonodavnoj vlasti } \\
\text { i javnosti najmanje } \\
\text { mjesec dana prije } \\
\text { početka financijske } \\
\text { godine te je odobren } \\
\text { i objavljen najviše } \\
\text { mjesec dana nakon } \\
\text { početka financijske } \\
\text { godine. }\end{array}$ & $\begin{array}{l}\text { Proračun se dostavlja } \\
\text { zakonodavnoj vlasti i } \\
\text { javnosti najmanje dva } \\
\text { mjeseca prije početka } \\
\text { financijske godine te je } \\
\text { odobren i objavljen } \\
\text { početkom financijske } \\
\text { godine. }\end{array}$ & $\begin{array}{l}\text { Proračun se dostavlja } \\
\text { zakonodavnoj vlasti i } \\
\text { javnosti najmanje tri } \\
\text { mjeseca prije početka } \\
\text { financijske godine te je } \\
\text { odobren i objavljen } \\
\text { barem mjesec dana } \\
\text { prije početka } \\
\text { financijske godine. }\end{array}$ \\
\hline
\end{tabular}




\begin{tabular}{|c|c|c|c|c|c|}
\hline \multirow{2}{*}{ BR. } & \multirow{2}{*}{ MJERA } & \multirow{2}{*}{ NAČELO } & \multicolumn{3}{|c|}{ Praksa } \\
\hline & & & TEMELjNA & DOBRA & NAPREDNA \\
\hline 2.3. & $\begin{array}{l}\text { Usmjerenost } \\
\text { politika }\end{array}$ & $\begin{array}{l}\text { Fiskalna predviđan } \\
\text { i utvrđivanje odgov }\end{array}$ & $\begin{array}{l}\text { i proračuni moraju bit } \\
\text { nosti. }\end{array}$ & predstavljeni tako da ol & kšavaju analizu mjera \\
\hline 2.3.I. & $\begin{array}{l}\text { Ciljevi fiskalne } \\
\text { politike }\end{array}$ & $\begin{array}{l}\text { Vlada utvrđuje i } \\
\text { obznanjuje jasne } \\
\text { i mjerljive ciljeve } \\
\text { javnih financija. }\end{array}$ & $\begin{array}{l}\text { Vlada utvrđuje i } \\
\text { redovito izvještava o } \\
\text { numeričkim ciljevima } \\
\text { glavnih fiskalnih } \\
\text { agregata na precizan } \\
\text { način ili u vremenski } \\
\text { određenim rokovima. }\end{array}$ & $\begin{array}{l}\text { Vlada utvrđuje i } \\
\text { redovito izvještava o } \\
\text { numeričkim ciljevima } \\
\text { glavnih fiskalnih } \\
\text { agregata na precizan } \\
\text { način i u vremenski } \\
\text { određenim rokovima. }\end{array}$ & $\begin{array}{l}\text { Vlada utvrđuje i } \\
\text { redovito izvještava o } \\
\text { numeričkim ciljevima } \\
\text { glavnih fiskalnih } \\
\text { agregata na precizan } \\
\text { način i u vremenski } \\
\text { određenim rokovima. } \\
\text { Takve procedure se } \\
\text { primjenjuju } 3 \text { ili više } \\
\text { godina. }\end{array}$ \\
\hline 2.3.2. & $\begin{array}{l}\text { Informacije } \\
\text { o izvršenju }\end{array}$ & $\begin{array}{l}\text { Proračunska } \\
\text { dokumentacija } \\
\text { pruža informacije } \\
\text { o ciljevima i } \\
\text { rezultatima } \\
\text { postignutim na } \\
\text { svakom glavnom } \\
\text { području vladinih } \\
\text { mjera. }\end{array}$ & $\begin{array}{l}\text { Proračunska } \\
\text { dokumentacija } \\
\text { uključuje informacije o } \\
\text { inputima nabavljenim } \\
\text { za svako glavno } \\
\text { područje vladinih } \\
\text { mjera. }\end{array}$ & $\begin{array}{l}\text { Proračunska } \\
\text { dokumentacija } \\
\text { izvještava o ciljevima } \\
\text { i izvođenju za outpute } \\
\text { koji se trebaju } \\
\text { isporučiti za svako } \\
\text { glavno područje } \\
\text { vladinih mjera. }\end{array}$ & $\begin{array}{l}\text { Proračunska } \\
\text { dokumentacija } \\
\text { izvještava o ciljevima } \\
\text { i izvođenju za ishode } \\
\text { koji se trebaju postići u } \\
\text { svakom glavnom } \\
\text { području vladinih } \\
\text { mjera. }\end{array}$ \\
\hline 2.3 .3 & $\begin{array}{l}\text { Sudjelovanje } \\
\text { javnosti }\end{array}$ & $\begin{array}{l}\text { Vlada građanima } \\
\text { pruža razumljiv } \\
\text { sažetak implikacija } \\
\text { proračunskih } \\
\text { mjera, uz njihovo } \\
\text { sudjelovanje } \\
\text { u odlučivanju } \\
\text { o proračunu. }\end{array}$ & $\begin{array}{l}\text { Vlada objavljuje i čini } \\
\text { dostupnim opis } \\
\text { aktualnih ekonomskih } \\
\text { i fiskalnih izvršenja i } \\
\text { planova, kao i sažetak } \\
\text { učinaka proračuna na } \\
\text { prosječnog građanina. }\end{array}$ & $\begin{array}{l}\text { Vlada objavljuje i čini } \\
\text { dostupnim opis } \\
\text { aktualnih ekonomskih } \\
\text { i fiskalnih izvršenja i } \\
\text { planova, kao i detaljan } \\
\text { izvještaj učinaka } \\
\text { proračuna na } \\
\text { prosječnog građanina, } \\
\text { te omogućava } \\
\text { građanima } \\
\text { izjašnjavanje pri } \\
\text { odlučivanju } \\
\text { o proračunu. }\end{array}$ & $\begin{array}{l}\text { Vlada objavljuje i čini } \\
\text { dostupnim opis } \\
\text { aktualnih ekonomskih } \\
\text { i fiskalnih izvršenja i } \\
\text { planova, kao i detaljan } \\
\text { izvještaj učinaka } \\
\text { proračuna na različite } \\
\text { demografske skupine, } \\
\text { te omogućava } \\
\text { građanima } \\
\text { izjašnjavanje } \\
\text { pri odlučivanju } \\
\text { o proračunu. }\end{array}$ \\
\hline
\end{tabular}

\begin{tabular}{|c|c|c|c|c|c|}
\hline 2.4 . & Pouzdanost & Ekonomska i fiskalv & predviđanja i proračun & noraju biti pouzdani. & \\
\hline 2.4.I. & $\begin{array}{l}\text { Nezavisna } \\
\text { evaluacija }\end{array}$ & $\begin{array}{l}\text { Vladina ekonomska } \\
\text { i fiskalna } \\
\text { predviđanja i } \\
\text { njihovo izvršenje } \\
\text { predmet su } \\
\text { nezavisne } \\
\text { evaluacije. }\end{array}$ & $\begin{array}{l}\text { Proračunska } \\
\text { dokumentacija } \\
\text { uključuje usporedbu } \\
\text { vladinih ekonomskih } \\
\text { i fiskalnih projekcija } \\
\text { s predviđanjima } \\
\text { nezavisnih } \\
\text { prognostičara. }\end{array}$ & $\begin{array}{l}\text { Nezavisan subjekt } \\
\text { ocjenjuje pouzdanost } \\
\text { vladinih ekonomskih } \\
\text { i fiskalnih predviđanja. }\end{array}$ & $\begin{array}{l}\text { Nezavisan subjekt } \\
\text { ocjenjuje pouzdanost } \\
\text { vladinih ekonomskih } \\
\text { i fiskalnih predviđanja, } \\
\text { kao i njihovo izvršenje } \\
\text { u odnosu na ciljeve } \\
\text { fiskalne politike. }\end{array}$ \\
\hline 2.4.2. & $\begin{array}{l}\text { Dopunski } \\
\text { proračun }\end{array}$ & $\begin{array}{l}\text { Svaka materijalna } \\
\text { promjena } \\
\text { odobrenog } \\
\text { proračuna usvaja } \\
\text { se u zakonodavnoj } \\
\text { proceduri. }\end{array}$ & $\begin{array}{l}\text { Dopunski proračun } \\
\text { naknadno uključuje } \\
\text { rashode koji premašuju } \\
\text { one odobrene } \\
\text { u proračunu. }\end{array}$ & $\begin{array}{l}\text { Dopunski proračun je } \\
\text { potreban prije } \\
\text { nastanka materijalnih } \\
\text { promjena ukupnih } \\
\text { rashoda predviđenih } \\
\text { proračunom. }\end{array}$ & $\begin{array}{l}\text { Dopunski proračun je } \\
\text { potreban prije } \\
\text { nastanka materijalnih } \\
\text { promjena ukupnih } \\
\text { rashoda predviđenih } \\
\text { proračunom ili bitnih } \\
\text { promjena njihova } \\
\text { sastava. }\end{array}$ \\
\hline
\end{tabular}




\begin{tabular}{|c|c|c|c|c|c|}
\hline \multirow{2}{*}{ BR. } & \multirow{2}{*}{ MJERA } & \multirow{2}{*}{ NAČELO } & \multicolumn{3}{|c|}{ PRAKSA } \\
\hline & & & TEMELJNA & DOBRA & NAPREDNA \\
\hline 2.4 .3 & $\begin{array}{l}\text { Usklađenost } \\
\text { predviđanja }\end{array}$ & $\begin{array}{l}\text { U proračunskoj } \\
\text { dokumentaciji i } \\
\text { svakom njenom } \\
\text { sljedećem } \\
\text { ažuriranju } \\
\text { objašnjene su sve } \\
\text { materijalne } \\
\text { promjene vladinih } \\
\text { prethodnih } \\
\text { fiskalnih } \\
\text { predviđanja, } \\
\text { razlikujući fiskalni } \\
\text { učinak novih mjera } \\
\text { od onih prvotnih. }\end{array}$ & $\begin{array}{l}\text { Razlike između } \\
\text { uzastopnih promjena } \\
\text { vladinih predviđanja } \\
\text { prihoda, rashoda i } \\
\text { financiranja prikazuju } \\
\text { se na agregatnoj razini, } \\
\text { uz kvalitativnu } \\
\text { raspravu o učincima } \\
\text { novih mjera na } \\
\text { predviđanja. }\end{array}$ & $\begin{array}{l}\text { Razlike između } \\
\text { uzastopnih promjena } \\
\text { vladinih predviđanja } \\
\text { prihoda, rashoda i } \\
\text { financiranja } \\
\text { razdvojene su na } \\
\text { ukupan učinak novih } \\
\text { mjera i } \\
\text { makroekonomskih } \\
\text { odrednica. }\end{array}$ & $\begin{array}{l}\text { Razlike između } \\
\text { uzastopnih promjena } \\
\text { vladinih predviđanja } \\
\text { prihoda, rashoda i } \\
\text { financiranja } \\
\text { razdvojene su na } \\
\text { učinke pojedinačnih } \\
\text { promjena određenih } \\
\text { mjera, } \\
\text { makroekonomskih } \\
\text { odrednica i ostalih } \\
\text { faktora, kao što su } \\
\text { tehničke i } \\
\text { računovodstvene } \\
\text { prilagodbe. }\end{array}$ \\
\hline 3. & $\begin{array}{l}\text { Analiza i } \\
\text { upravljanje } \\
\text { fiskalnim } \\
\text { rizicima } \\
\end{array}$ & \multicolumn{4}{|c|}{$\begin{array}{l}\text { Vlade trebaju objavljivati, analizirati i upravljati rizicima javnih financija i osigurati } \\
\text { efikasnu koordinaciju fiskalnog odlučivanja u okviru cijelog javnog sektora. }\end{array}$} \\
\hline 3.I. & $\begin{array}{l}\text { Objava rizika } \\
\text { i analize }\end{array}$ & \multicolumn{4}{|c|}{ Vlade trebaju redovito objavljivati sažeta izvješća o rizicima fiskalnih predviđanja. } \\
\hline 3.I.I. & $\begin{array}{l}\text { Makroekonomski } \\
\text { rizici }\end{array}$ & $\begin{array}{l}\text { Vlada izvještava } \\
\text { o mogućim } \\
\text { odstupanjima } \\
\text { fiskalnih rezultata u } \\
\text { odnosu na osnovna } \\
\text { predviđanja, kao } \\
\text { rezultat različitih } \\
\text { makroekonomskih } \\
\text { pretpostavki. }\end{array}$ & $\begin{array}{l}\text { Proračunska } \\
\text { dokumentacija } \\
\text { uključuje raspravu o } \\
\text { osjetljivosti fiskalnih } \\
\text { predviđanja na glavne } \\
\text { makroekonomske } \\
\text { pretpostavke. }\end{array}$ & $\begin{array}{l}\text { Proračunska } \\
\text { dokumentacija } \\
\text { uključuje analizu } \\
\text { osjetljivosti te } \\
\text { alternativne } \\
\text { makroekonomske } \\
\text { i fiskalne scenarije. }\end{array}$ & $\begin{array}{l}\text { Proračunska } \\
\text { dokumentacija } \\
\text { uključuje analizu } \\
\text { osjetljivosti, } \\
\text { alternativne scenarije } \\
\text { i probabilistička } \\
\text { predviđanja fiskalnih } \\
\text { ishoda. }\end{array}$ \\
\hline 3.I.2. & $\begin{array}{l}\text { Posebni fiskalni } \\
\text { rizici }\end{array}$ & $\begin{array}{l}\text { Vlada pruža } \\
\text { redovito sažeto } \\
\text { izvješće o glavnim } \\
\text { posebnim rizicima u } \\
\text { fiskalnim } \\
\text { predviđanjima. }\end{array}$ & $\begin{array}{l}\text { Glavni posebni rizici } \\
\text { vezani uz fiskalna } \\
\text { predviđanja objavljuju } \\
\text { se u sažetom izvješću } \\
\text { i o njima se raspravlja u } \\
\text { kvalitativnim } \\
\text { terminima. }\end{array}$ & $\begin{array}{l}\text { Glavni posebni rizici } \\
\text { vezani uz fiskalna } \\
\text { predviđanja objavljuju } \\
\text { se u sažetom izvješću } \\
\text { uz ocjene njihovih } \\
\text { veličina. }\end{array}$ & $\begin{array}{l}\text { Glavni posebni rizici } \\
\text { vezani uz fiskalna } \\
\text { predviđanja objavljuju } \\
\text { se u sažetom izvješću uz } \\
\text { ocjene njihovih veličina } \\
\text { i, gdje je moguće, uz } \\
\text { ocjenu vjerojatnosti } \\
\text { njihove pojave. }\end{array}$ \\
\hline 3.I.3. & $\begin{array}{l}\text { Analize } \\
\text { dugoročne } \\
\text { fiskalne održivosti }\end{array}$ & $\begin{array}{l}\text { Vlada redovito } \\
\text { objavljuje } \\
\text { dugoročne } \\
\text { projekcije razvoja } \\
\text { javnih financija. }\end{array}$ & $\begin{array}{l}\text { Vlada redovito } \\
\text { objavljuje projekcije } \\
\text { održivosti glavnih } \\
\text { fiskalnih agregata i svih } \\
\text { fondova zdravstvenog i } \\
\text { socijalnog osiguranja } \\
\text { u razdoblju od barem } \\
\text { Io sljedećih godina. }\end{array}$ & $\begin{array}{l}\text { Vlada redovito } \\
\text { objavljuje više } \\
\text { scenarija održivosti } \\
\text { glavnih fiskalnih } \\
\text { agregata i svih fondova } \\
\text { zdravstvenog i } \\
\text { socijalnog osiguranja u } \\
\text { razdoblju od barem } 30 \\
\text { sljedećih godina, } \\
\text { koristeći određeni broj } \\
\text { makroekonomskih } \\
\text { pretpostavki. }\end{array}$ & $\begin{array}{l}\text { Vlada redovito } \\
\text { objavljuje više scenarija } \\
\text { održivosti glavnih } \\
\text { fiskalnih agregata i svih } \\
\text { fondova zdravstvenog i } \\
\text { socijalnog osiguranja u } \\
\text { razdoblju od barem } 30 \\
\text { sljedećih godina, } \\
\text { koristeći određeni broj } \\
\text { makroekonomskih, } \\
\text { demografskih ili drugih } \\
\text { pretpostavki, } \\
\text { te pretpostavki vezanih } \\
\text { uz prirodne resurse. }\end{array}$ \\
\hline 3.2. & $\begin{array}{l}\text { Upravljanje } \\
\text { rizicima }\end{array}$ & \multicolumn{4}{|c|}{ Posebne rizike u javnim financijama treba redovito nadzirati, objavljivati te s njima upravljati. } \\
\hline 3.2.I. & $\begin{array}{l}\text { Nepredviđene } \\
\text { okolnosti vezane } \\
\text { uz proračun }\end{array}$ & $\begin{array}{l}\text { U proračunu su } \\
\text { transparentno } \\
\text { alocirana dovoljna } \\
\text { sredstva za } \\
\text { nepredviđene } \\
\text { okolnosti koje se } \\
\text { javljaju tijekom } \\
\text { izvršenja proračuna. }\end{array}$ & $\begin{array}{l}\text { Proračun uključuje } \\
\text { alocirana sredstva za } \\
\text { nepredviđene } \\
\text { okolnosti. }\end{array}$ & $\begin{array}{l}\text { Proračun uključuje } \\
\text { alocirana sredstva za } \\
\text { nepredviđene } \\
\text { okolnosti s } \\
\text { transparentnim } \\
\text { kriterijima za njihovu } \\
\text { dodjelu. }\end{array}$ & $\begin{array}{l}\text { Proračun uključuje } \\
\text { alocirana sredstva } \\
\text { za nepredviđene } \\
\text { okolnosti s } \\
\text { transparentnim } \\
\text { kriterijima za njihovu } \\
\text { dodjelu, uz redovito } \\
\text { izvještavanje o njihovoj } \\
\text { upotrebi tijekom } \\
\text { godine. }\end{array}$ \\
\hline
\end{tabular}




\begin{tabular}{lll} 
BR. & MJERA & NAČELO \\
\cline { 1 - 1 } & & \\
3.2.2. & $\begin{array}{l}\text { Upravljanje } \\
\text { obvezama }\end{array}$ & $\begin{array}{l}\text { Upravlja se rizicima } \\
\text { vezanim uz glavne } \\
\text { oblike imovine i } \\
\text { obveza te ih se } \\
\text { objavljuje. }\end{array}$
\end{tabular}

$\begin{array}{lll} & & \\ & & \\ & & \\ \text { 3.2.3. } & \text { Jamstoženost vlade } \\ & & \text { jamstvima redovito } \\ & \text { se objavljuje i } \\ & \text { zakonski odobrava. }\end{array}$

$\begin{array}{lll} & \begin{array}{l}\text { Obveze u javno- } \\ \text { privatnom } \\ \text { partnerstvu }\end{array} \\ \text { 3.2.4. } & \text { Javno privatno- } & \text { redovito se } \\ \text { partnerstvo } & \text { objavljuju te se } \\ \text { njima aktivno } \\ \text { upravlja. }\end{array}$

$-$

$\begin{array}{lll} & \text { Vladina potencijalna } \\ & \text { fiskalna izloženost } \\ \text { 3.2.5. } & \text { financijskom } & \text { financijskom } \\ \text { sektoru } & \text { sektoru se analizira, } \\ & \text { objavljuje te se } \\ & \text { njome upravlja. }\end{array}$

\begin{tabular}{|c|c|c|}
\hline 3.2 .6 & Prirodni resursi & $\begin{array}{l}\text { Vladin udio u } \\
\text { neobnovljivim } \\
\text { prirodnim } \\
\text { resursima i njihovo } \\
\text { iskorištavanje se } \\
\text { vrednuje, objavljuje } \\
\text { i njima se upravlja. }\end{array}$ \\
\hline
\end{tabular}

\begin{tabular}{|c|c|c|}
\hline 3.2.7. & Rizici po okoliš & $\begin{array}{l}\text { Potencijalna } \\
\text { fiskalna izloženost } \\
\text { prirodnim } \\
\text { nepogodama i } \\
\text { drugim većim } \\
\text { rizicima po okoliš se } \\
\text { analizira, objavljuje i } \\
\text { njome se upravlja. }\end{array}$ \\
\hline
\end{tabular}

\begin{tabular}{ll}
\cline { 1 - 1 } \multicolumn{1}{c}{ TEMELjNa } & \multicolumn{1}{c}{ PraKsa } \\
\cline { 1 - 1 } $\begin{array}{ll}\text { Svako zaduživanje } \\
\text { odobreno je zakonom, }\end{array}$ \\
$\begin{array}{ll}\text { a rizici vezani uz vladin } \\
\text { dug se analiziraju i } \\
\text { objavljuju. }\end{array}$ & $\begin{array}{l}\text { Svako zaduživanje } \\
\text { odobreno je zakonom, } \\
\text { a rizici vezani uz } \\
\text { vladinu financijsku } \\
\text { imovinu i obveze se } \\
\text { analiziraju i objavljuju. }\end{array}$
\end{tabular}

Sva vladina jamstva,

Sva vladina jamstva, njihovi korisnici i a, bruto izloženost koju njihovi korisnici i bruto stvaraju, objavljuju se izloženost koju stvaraju, objavljuju se barem jednom godišnje. barem jednom godišnje. Zakonom se odobrava maksimalna vrijednost novih jamstava ili njihov ukupan iznos.

Vlada barem jednom godišnje objavljuje svoja ukupna prava, obveze i ostalu izloženost $u$ ugovorima o javnoprivatnom partnerstvu, i očekivana godišnja primanja i plaćanja tijekom trajanja ugovora.

Vlada barem jednom svoja ukupna prava obveze i ostalu izloženost u ugovorima o javno-privatnom partnerstvu.
Vlasti barem jednom godišnje kvantificiraju i objavljuju eksplicitnu potporu financijskom sektoru.
Vlasti barem jednom godišnje kvantificiraju i objavljuju eksplicitnu potporu financijskom sektoru

i redovito procjenjuju njegovu stabilnost.

\section{Vlada objavljuje} godišnje ocjene obujma i vrijednosti glavnih oblika imovine sadržane u prirodnim resursima, kao i obujam i vrijednost prošlogodišnjih prodaja i njihov fiskalni prihod.

Vlada identificira glavne fiskalne rizike prirodnih nepogoda i raspravlja o njima u kvalitativnim terminima.
Vlada objavljuje godišnje ocjene obujma i vrijednosti glavnih oblika imovine sadržane u prirodnim resursima uz različite cjenovne scenarije, kao i obujam i vrijednost prošlogodišnjih prodaja i njihov fiskalni prihod.

Vlada identificira glavne fiskalne rizike prirodnih nepogoda i raspravlja o njima, kvantificirajući ih s obzirom na povijesna iskustva.

\section{NAPREDNA}

Sve obveze, važna stjecanja i prodaja imovine odobreni su zakonom, a rizici vezani uz bilancu stanja se objavljuju i njima se upravlja u skladu s objavljenom strategijom.

Sva vladina jamstva, njihovi korisnici, bruto izloženost koju stvaraju i vjerojatnost njihova opoziva, objavljuju se barem jednom godišnje.

Zakonom se odobrava maksimalna vrijednost novih jamstava ili njihov ukupan iznos.

Vlada barem jednom godišnje objavljuje svoja ukupna prava, obveze i ostalu izloženost u ugovorima o javno-privatnom partnerstvu, i očekivana godišnja primanja i plaćanja tijekom trajanja ugovora. Postavljen je i zakonski limit na akumulirane obveze.

Vlasti barem jednom godišnje kvantificiraju i objavljuju eksplicitnu potporu financijskom sektoru i redovito procjenjuju njegovu stabilnost. Procjena

je zasnovana na mogućem spektru makroekonomskih i financijskih scenarija.

Vlada objavljuje godišnje ocjene obujma i vrijednosti glavnih oblika imovine sadržane $u$ prirodnim resursima uz različite cjenovne i

eksploatacijske scenarije, kao i obujam i vrijednost prošlogodišnjih prodaja i njihov fiskalni prihod.

Vlada identificira glavne fiskalne rizike prirodnih nepogoda i raspravlja o njima, kvantificirajući ih s obzirom na povijesna iskustva, i njima upravlja u skladu s objavljenom strategijom. 


\begin{tabular}{|c|c|c|c|c|c|}
\hline \multirow{2}{*}{ BR. } & \multirow{2}{*}{ MJERA } & \multirow{2}{*}{ NAČELO } & \multicolumn{3}{|c|}{ PraKsa } \\
\hline & & & TEMELJNA & DOBRA & NAPREDNA \\
\hline 3.3 . & $\begin{array}{l}\text { Fiskalna } \\
\text { koordinacija }\end{array}$ & \multicolumn{4}{|c|}{$\begin{array}{l}\text { Fiskalni odnosi i rezultati u cijelom javnom sektoru trebaju se analizirati, objavljivati } \\
\text { i koordinirati. }\end{array}$} \\
\hline 3.3.I. & Lokalne jedinice & $\begin{array}{l}\text { Prikupljaju se } \\
\text { i objavljuju } \\
\text { sveobuhvatne } \\
\text { informacije o } \\
\text { financijskom stanju } \\
\text { i rezultatima } \\
\text { lokalnih jedinica - } \\
\text { zasebno } \\
\text { i konsolidirano za } \\
\text { sve lokalne jedinice. }\end{array}$ & $\begin{array}{l}\text { Financijsko stanje } \\
\text { i izvršenje lokalnih } \\
\text { jedinica objavljuju } \\
\text { se godišnje. }\end{array}$ & $\begin{array}{l}\text { Financijsko stanje } \\
\text { i izvršenje lokalnih } \\
\text { jedinica objavljuju } \\
\text { se godišnje, uz limit } \\
\text { na njihove obveze ili } \\
\text { zaduživanje. }\end{array}$ & $\begin{array}{l}\text { Financijsko stanje } \\
\text { i izvršenje lokalnih } \\
\text { jedinica objavljuju } \\
\text { se kvartalno, uz limit } \\
\text { na njihove obveze ili } \\
\text { zaduživanje. }\end{array}$ \\
\hline 3.3 .2$. & Javna poduzeća & $\begin{array}{l}\text { Vlada redovito } \\
\text { objavljuje } \\
\text { sveobuhvatne } \\
\text { informacije o } \\
\text { financijskim } \\
\text { rezultatima } \\
\text { javnih poduzeća, } \\
\text { uključujući sve } \\
\text { njihove } \\
\text { kvazifiskalne } \\
\text { aktivnosti. }\end{array}$ & $\begin{array}{l}\text { Svi transferi između } \\
\text { vlade i javnih poduzeća } \\
\text { objavljuju } \\
\text { se barem jednom } \\
\text { godišnje. }\end{array}$ & $\begin{array}{l}\text { Objavljuju se svi } \\
\text { transferi između vlade } \\
\text { i javnih poduzeća, te se } \\
\text { na osnovu objavljene } \\
\text { vlasničke politike, } \\
\text { barem jednom } \\
\text { godišnje objavljuje } \\
\text { izvješće } \\
\text { o ukupnom } \\
\text { financijskom izvršenju } \\
\text { sektora javnih } \\
\text { poduzeća. }\end{array}$ & $\begin{array}{l}\text { Objavljuje se ukupna } \\
\text { izravna i neizravna } \\
\text { potpora vlade javnim } \\
\text { poduzećima, } \\
\text { zasnovana na } \\
\text { objavljenoj vlasničkoj } \\
\text { politici. Izvješće o } \\
\text { ukupnom financijskom } \\
\text { izvršenju sektora } \\
\text { javnih poduzeća, } \\
\text { uključujući i ocjene } \\
\text { svih poduzetih } \\
\text { kvazifiskalnih } \\
\text { aktivnosti, objavljuje } \\
\text { se barem jednom } \\
\text { godišnje. }\end{array}$ \\
\hline
\end{tabular}

\section{G. PoJMOVNIK}

Godišnja financijska izvješća. Podskupovi financijskih izvješća koja se donose krajem godine. Kada se koristi obračunski sustav, godišnja financijska izvješća uključuju najmanje bilancu stanja, izvještaj o prihodima i rashodima, primicima i izdacima, izvješće o tokovima gotovine te bilješke. Koristi li se gotovinski obračunski sustav, godišnje se financijsko izvješće prikazuje kao izvješće o gotovinskim tokovima i može sadržavati izvješće o izvršenju proračuna za kraj godine. Očekuje se da se godišnja financijska izvješća temelje na odgovarajućim računovodstvenim standardima i općeprihvaćenim računovodstvenim načelima. Općenito, godišnja financijska izvješća podvrgnuta su reviziji te se javno objavljuju; u slučajevima kada nisu podvrgnuta reviziji, koriste se konačna godišnja financijska izvješća.

Bilanca stanja. Sveobuhvatno i konsolidirano izvješće o imovini, obvezama i neto vrijednosti vlade ili javnog sektora na kraju obračunskog razdoblja. Uključuje financijsku i nefinancijsku te domaću i inozemnu imovinu i obveze, kao i dodatne informacije o njima.

Zaduživanje. Oblici vladinog zaduživanja, uključujući obveznice, trezorske zapise i bankarske kredite te neizravno zaduživanje kao što su plativi računi, dospjele neplaćene obveze po rashodima i neplaćanje povrata poreza.

Proračunska dokumentacija. Sva dokumentacija koja se objavljuje u ili oko vremena izrade godišnjeg proračuna uključujući i prijedlog proračuna, proračunske procjene, fiskalne strategije, srednjoročne proračunske okvire, izvješća o fiskalnim rizicima, prijedloge financijskih zakona ili prijedloge zakona o izvršenju proračuna, dugoročna izvješća o javnim financijama, te zakone o proračunu, financijama ili proračunskoj raspodjeli.

Potencijalne obveze. Obveze plaćanja, vremenom i iznosom ovisne o pojavi nekog posebnog nesigurnog događaja ili skupine budućih događaja. Primjerice, jamstva, obeštećenja, te tzv. pisma podrške (engl. letters of comfort).

Analiza raspodjele. Kvantitativna ocjena utjecaja posebnih ili općih vladinih politika na različite segmente stanovništva, često diferencirane prema dohotku, spolu ili geografskom položaju. Primjerice, utjecaj promjena poreznih stopa na različite dohodovne decile. 
Dospjele neplaćene obveze po rashodima. Iznosi koji su neplaćeni i za koje je prošao datum dospijeća. To je ukupno stanje računâ koji nisu plaćeni na datum u ugovoru ili u redovno vrijeme koje na tržištu postoji za slične transakcije. Mogu nastati radi vladinih neplaćanja, kao u slučaju računa dobavljačima kojima su prošli datumi dospijeća te datumi za plaće i transfere ili je prošao rok za otplatu duga ili za plaćanje servisiranja duga.

Financijski derivati. Financijski instrument povezan s drugim posebnim financijskim instrumentom, pokazateljem ili robom, s pomoću kojeg se može trgovati posebnim financijskim rizicima (primjerice, kamatni rizik, valutni rizik, rizik cijena dionica ili roba i kreditni rizik) na financijskim tržištima. Primjeri: ročnice (engl. futures), zamjene ili swapovi (engl. swaps) i opcije (engl. options).

Fiskalni agregati. Zbirni fiskalni pokazatelji koji na strani tokova uključuju ukupne rashode i prihode, neto posudbe/neto zaduživanje ili ukupna fiskalna salda; na strani stanja uključuju bruto i neto dug, ukupnu imovinu, ukupne obveze i neto vrijednost.

Fiskalna predviđanja. Predviđanja glavnih fiskalnih agregata, kao i elemenata na kojima se zasnivaju, uključivo glavne prihodne stavke; rashode po organizacijskoj, funkcionalnoj ili ekonomskoj klasifikaciji; glavne oblike imovine i obveza, uključivo bruto dug.

Fiskalno zakonodavstvo. Zakoni koji su vezani uz formulaciju fiskalne politike; pripremu, donošenje i izvršenje proračuna; i/ili obračun, izvještavanje i reviziju fiskalnih informacija. Uključuju fiskalnu odgovornost, organske zakone o proračunu, javno upravljanje financijama i javno računovodstvo te zakonodavstvo vezano uz reviziju.

Fiskalna izvješća. Retrospektivna izvješća o odvijanju fiskalnih događaja koja uključuju izviješća o izvršenju proračuna tijekom i krajem godine, fiskalnu statistiku i godišnja fiskalna izvješća.

Fiskalna statistika. Retrospektivna izvješća o vladinim financijskim rezultatima koja sadrže fiskalne podatke zasnovane na međunarodnim statističkim standardima, kao što su Priručnik o državnoj financijskoj statistici (200I. ili 20I4.) - engl. Government Finance Statistics Manual ili Sustav nacionalnih računa - engl. System of National Accounts) (1993. ili 2008.) ili Europski sustav nacionalnih računa (1995. ili 20Io.) - engl. European System of National Accounts.

Opća država. Sektor opće države sastoji se od rezidentnih institucionalnih jedinica kojima je primarna djelatnost ispunjavanje državnih funkcija. Uključuje sva državna tijela središnje, državne, pokrajinske, regionalne i lokalne vlade, fondove socijalnog osiguranja i netržišne neprofitne institucije koje kontroliraju državna tijela (obično izvanproračunski fondovi), kako je definirano GFSM2OI4 - engl. Government Finance Statistics Manual 20I4. Uključuje i poduzeća koja su zakonski osnovana kao dionička društva, ali dobra i usluge pružaju prvenstveno na netržišnoj osnovi.

Državno jamstvo. Najuobičajeniji mu je oblik zahtjev da država plati nepodmireni iznos kredita u slučaju da treća strana to nije učinila. U nekim ugovorima - posebno vezanim uz javno-privatno partnerstvo - država može osigurati prihod ili tražiti jamstvo za pokrivanje razlike ako prihod ili potražnja ne pokrivaju dogovorenu razinu. Ostali ugovori mogu uključivati cjenovno ili valutno jamstvo.

Nezavisno tijelo. Tijelo za djelotvorno provođenje revizije ili pripremu fiskalne statistike, s dovoljno širokim ovlastima i punom profesionalnom slobodom u obavljanju svojih funkcija, pravom i obvezom izvještavanja o vlastitom radu, s neograničenim pristupom informacijama i odgovarajućim ljudskim, materijalnim i novčanim resursima, što je sve definirano zakonodavnim okvirom.

Međunarodni standardi. Međunarodno priznati standardi za: I.) financijsku statistiku vlade, uključujući Priručnik državne financijske statistike (200I. ili 20I4.) - engl. Government Finance Statistics Manual, ili Sustav nacionalnih računa - engl. System of National Accounts (1993. ili 2008.), ili Europski sustav nacionalnih računa (1995. ili 20Io.) - engl. European System of National Accounts; 2.) vladina financijska izvješća, uključujući Međunarodne računovodstvene standarde za javni sektor - engl. International Public Sector Accounting Standards (IPSAS) i Međunarodne standarde financijskog izvještavanja - engl. International Financial Reporting Standards (IFRS). 
Fiskalna izvješća tijekom godine. Izvješća o izvršenju proračuna i fiskalna statistika, izrađuju se mjesečno ili kvartalno tijekom financijske godine, ali mogu uključivati i cjelogodišnja izvješća koja se izrađuju odmah nakon završetka financijske godine.

Makroekonomski rizici. Rizici koji nastaju kada su makroekonomska ostvarenja različita od predviđanja. Primjerice, kada su BDP, inflacija, nezaposlenost, cijene roba ili tečajevi iznad ili ispod proračunskih predviđanja.

Glavne revizorske kvalifikacije. Uključuju jedno od sljedećeg: I.) ograničeno revizijsko mišljenje; 2.) nepovoljno revizijsko mišljenje; 3.) svaku revizijsku kvalifikaciju čiji financijski učinak, po procjeni revizora, iznosi jedan ili više posto BDP-a.

Glavne izmjene. Izmjene povijesne fiskalne statistike, dovoljno velike da imaju presudan makro učinak na ključne fiskalne agregate; svaka izmjena koja iznosi jedan ili više posto BDP-a.

Srednji rok. Tri do pet godina nakon tekuće godine.

Višegodišnji ugovori. Ugovori između vlade i privatnog sektora, sklopljeni na razdoblje dulje od godine dana, kao što su javno-privatno partnerstvo, dugoročni najam i dugoročne nabave.

Dugi rok. Razdoblje od deset ili više godina nakon tekuće godine.

Javna aktivnost. Sve fiskalne aktivnosti koje poduzimaju tijela javnog sektora.

Javna poduzeća. Poduzeća u vlasništvu ili pod kontrolom državnih tijela i/ili drugih javnih poduzeća, što je definirano Priručnikom državne financijske statistike (200I. ili 20I4.) - engl. Government Finance Statistics Manual.

Javno-privatno partnerstvo. Dugoročni ugovor između dvaju subjekata, po kojem jedan subjekt stječe ili gradi neku imovinu ili skupinu imovine, upravlja njome neko vrijeme, a potom ju predaje drugom subjektu. Privatni sektor pruža infrastrukturu i usluge koje uobičajeno pruža država (bolnice, škole, zatvori, ceste, mostovi, željeznica te vodna i sanitarna postrojenja). Slučajevi kada privatni operater snosi određenu odgovornost u upravljanju imovinom, uz stanovita ulaganja, nazivaju se koncesijama.

Javni sektor. Sastoji se od rezidentnih institucionalnih tijela koja izravno ili neizravno kontroliraju rezidentna državna tijela - sva tijela opće države i rezidentna javna poduzeća (uključujući nefinancijska i financijska javna poduzeća).

Kvazifiskalne aktivnosti. Državne operacije koje obavljaju institucije koje nisu državna tijela (središnje banke i ostala javna poduzeća). Primjerice, koncesijski krediti središnje banke, izravne posudbe javnih poduzeća i zahtjevi da javna ili privatna poduzeća pružaju usluge ispod cijene.

Poluautonomno tijelo. Dio državnog sektora koji, u usporedbi s vladinim ministarstvima i tijelima, uživa određenu de facto ili de jure operativnu i financijsku autonomiju pri zapošljavanju, upravljanju proračunom i internoj organizaciji.

Poseban fiskalni rizik. Rizik koji nije izravno vezan uz makroekonomske čimbenike. Užeg je karaktera i posebnog podrijetla, a aktiviraju ga nenadani događaji poput opoziva jamstva, prirodne nepogode ili sanacije banke.

Lokalne jedinice. Državne, pokrajinske ili regionalne vlade, kao i lokalne vlade kako ih definira Priručnik državne financijske statistike (200I. ili 20I4.) - engl. Government Finance Statistics Manual.

Porezni izdaci. Povlastice, oslobođenja, umanjenja ili izuzeća od "normalne” porezne strukture, koji smanjuju državne prihode. Budući da vlada može posegnuti za alternativnim mjerama kao što su subvencije ili izravni izdaci, oni se smatraju ekvivalentom proračunskim rashodima. 